\title{
APPEARANCE, \\ DISCRIMINATION \\ AND THE MEDIA
}

\section{Portraying Facial Disfigurement \\ Fairly in the News}

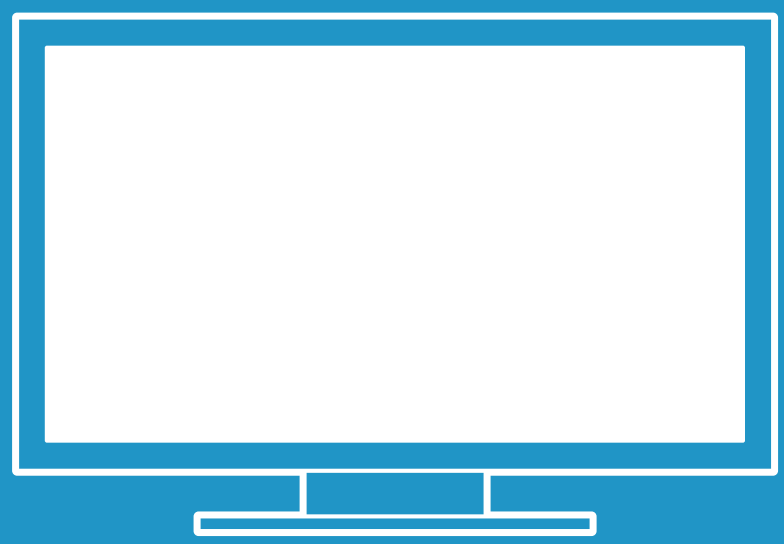

\section{DIANA GARRISI}

LAIMA JANCIUTE and 


\section{THE AUTHORS}

DR DIANA GARRISI is Lecturer at the JS School of Film and TV Arts, Xi'an Jiaotong - Liverpool University, China. She is currently co-editing with Jacob Johanssen a book exploring media portrayals of disability from a global perspective.

DR LAIMA JANCIUTE was Research Fellow of the Policy Observatory at the Communication and Media Research Institute (CAMRI), University of Westminster.

DR JACOB JOHANSSEN is Senior Lecturer at the Communication and Media Research Institute (CAMRI), University of Westminster. His monograph Psychoanalysis and Digital Culture: Audiences, Social Media and Big Data will be published by Routledge in 2018 and with Diana Garrisi he is co-editing a book exploring media portrayals of disability from a global perspective.

\section{ABOUT CAMRI}

\section{CAMRI \\ UNIVERSITYOF WESTMINSTER ${ }^{\prime \prime}$}

CAMRI (the Communication and Media Research Institute) at the University of Westminster is a world-leading centre of media and communication research. It is renowned for critical and international research that investigates the role of media, culture and communication(s) in society.

CAMRI's research is based on a broader purpose and vision for society: its work examines how the media and society interact and aims to contribute to progressive social change, equality, freedom, justice, and democracy. CAMRI takes a public interest and humanistic approach that seeks to promote participation, facilitate informed debate, and strengthen capabilities for critical thinking, complex problem solving and creativity.

\section{camri.ac.uk}




\section{SERIES DESCRIPTION}

The CAMRI Policy Brief series provides rigorous and evidence-based policy advice and policy analysis on a variety of media and communicationrelated topics. In an age where the accelerated development of media and communications creates profound opportunities and challenges for society, politics and the economy, this series cuts through the noise and offers up-to-date knowledge and evidence grounded in original research in order to respond to these changes in all their complexity.

By using Open Access and a concise, easy-to-read format, this peerreviewed series aims to make new research from the University of Westminster available to the public, to policymakers, practitioners, journalists, activists and scholars both nationally and internationally.

\section{camri.ac.uk/policy-observatory}

\section{CAMRI Policy Briefs (2018)}

\section{Series Editors:}

Professor Steve Barnett

Professor Christian Fuchs

Dr Anastasia Kavada

Nora Kroeger

Dr Maria Michalis

THE ONLINE ADVERTISING TAX: A Digital Policy Innovation Christian Fuchs

ARTIFICIAL INTELLIGENCE AND THE INTERNET OF THINGS Mercedes Bunz and Laima Janciute

APPEARANCE, DISCRIMINATION AND THE MEDIA

Diana Garrisi, Laima Janciute, and Jacob Johanssen

WELL-BEING AND MENTAL HEALTH IN THE GIG ECONOMY Sally-Anne Gross, George Musgrave and Laima Janciute

\section{CAMRI extended policy report (2018)}

THE ONLINE ADVERTISING TAX AS THE FOUNDATION OF A PUBLIC SERVICE INTERNET

Christian Fuchs 


\title{
APPEARANCE, DISCRIMINATION AND THE MEDIA
}

\section{PORTRAYING FACIAL DISFIGUREMENT FAIRLY INTHE NEWS}

\author{
Diana Garrisi, Laima Janciute and \\ Jacob Johanssen
}

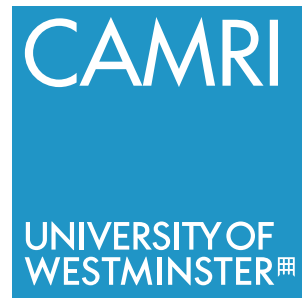




\author{
Published by \\ University of Westminster Press \\ 115 New Cavendish Street \\ London W1W 6UW \\ www.uwestminsterpress.co.uk
}

Text @ Diana Garrisi, Laima Janciute and Jacob Johanssen

First published 2018

Cover: ketchup-productions.co.uk

Digital versions typeset by Siliconchips Services Ltd.

ISBN (Paperback): 978-1-912656-22-6 (not available for sale)

ISBN (PDF): 978-1-912656-23-3

ISBN (EPUB): 978-1-912656-24-0

ISBN (Kindle): 978-1-912656-25-7

DOI: https://doi.org/10.16997/book31

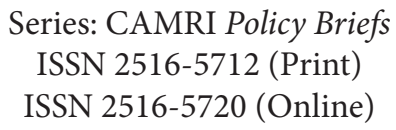

This work is licensed under the Creative Commons Attribution-NonCommercialNoDerivatives 4.0 International License. To view a copy of this license, visit http://creativecommons.org/licenses/by-nc-nd/4.0/ or send a letter to Creative Commons, 444 Castro Street, Suite 900, Mountain View, California, 94041, USA. This license allows for copying and distributing the work, providing author attribution is clearly stated, that you are not using the material for commercial purposes and that modified versions are not distributed.

The full text of this book has been peer-reviewed to ensure high academic standards. For full review policies, see: http://www.uwestminsterpress.co.uk/ site/publish/

\title{
Suggested citation:
}

Garrisi, Diana, Janciute, Laima and Johanssen, Jacob. 2018 Appearance, Discrimination and the Media. London: University of Westminster Press. DOI: https://doi.org/10.16997/book31.

License: CC-BY-NC-ND 4.0

To read the free, open access version of this book online, visit https://doi.org/10.16997/book31 or scan this QR code with your mobile device: 


\section{CONTENTS}

Key Messages

What's the Issue? $\quad 6$

Research Evidence $\quad 10$

The Depiction of Disfigurement and Disability in the Media 10

Framing Disfigurement in the UK National Press II

Coverage of Facial Disfigurement as a Result of Acid Attacks in the UK Tabloid Press

Journalistic Representation of Disfigurement

Versus Practices of Self-Representation Online $\quad 16$

Review of Policy Options 18

Policy Recommendations 21

Notes $\quad 23$ 


\section{APPEARANCE, DISCRIMINATION AND THE MEDIA}

\section{? Key Messages}

The portrayal of disfigurement in the UK media must change. This policy brief addresses one of the most persistent social problems: the stigmatisation of non-conforming physical characteristics. More than 500,000 people in the UK have facial disfigurements and more than 1 million have significant disfigurements to their face and body. ${ }^{1}$ Disfigurement generally refers to having one's appearance affected by a congenital or acquired medical condition.

Since the first face transplant was carried out in 2005 on Isabelle Dinoire, whose face had been mauled by a dog, media interest in facial disfigurement has increasingly raised ethical issues regarding facial diversity that can no longer be ignored. ${ }^{2}$ Furthermore, the five-fold rise in acid attacks in recent years has led to increased UK press coverage on disfigurement caused by burns.

Research evidence by Diana Garrisi and Jacob Johanssen yields the following findings:

$>$ The depiction of disfigurement in the British press portrays people who have a condition affecting their face in a general stereotypical and sensationalised manner. 
$>$ However, self-representation of disfigurement on social media, for example, can work complementary to and alongside more traditional forms of journalism and offer an alternative way for talking about disfigurement.

There needs to be a concerted effort to shape a community of citizens where people with visible difference are treated fairly and are given protection from discrimination:

$>$ Media coverage of disfigurements should move away from sensationalist depictions and focus on the everyday, lived experiences of individuals with a visible physical difference.

$>$ The media industry should adopt stronger diversityoriented editorial practices and provide training for media professionals, where necessary, on fair and discreet portrayal of disfigurement and disability.

$>$ Regulatory bodies should issue guidelines on the portrayal of disfigurement and handle complaints and issues more efficiently. 


\section{WHAT'S THE ISSUE?}

One in $111(542,000)$ people in the UK have facial disfigurements and one in $44(1,345,000)$ have a significant disfigurement to their face and body. ${ }^{3}$ Around 15,000 children are born in the UK every year with a disfigurement. ${ }^{4}$ Disfigurement can be defined as having one's appearance affected by a congenital or acquired medical condition. Causes of appearance change can stem from: burns; birthmarks; scars; craniofacial conditions; skin diseases and the impacts of head and neck cancers.

People affected by a visible difference can suffer twice, firstly from the cause or condition, and secondly from appearancerelated prejudice and discrimination, often on a daily basis. These findings are widely documented in the research literature and demonstrated by the report on Disfigurement in the UK, published in 2017 by the national charity Changing Faces. 'Disfigurement can affect anyone from any social or demographic group and at any time in life. ${ }^{5}$ Severe facial disfigurement is considered a disability under the Equality Act 2010.

People with visible or invisible physical impairments face social stigma, discrimination, prejudice and exclusion in public life. ${ }^{6}$ The prejudice which people harbour towards disfigurement is far higher than prejudice towards ethnicity or gender. ${ }^{7}$ 


\section{'People affected by a visible difference can suffer twice, firstly from the cause or condition, and secondly from appearance-related prejudice and discrimination, often on a daily basis.'}

'A public attitude survey found 67\% of the general public find it difficult to attach positive qualities to people with disfigurements.' Having a disfigurement therefore means having to face very challenging life experiences.

The report Disfigurement in the $U K^{9}$ produced by the charity Changing Faces in 2017 showed that:

$>$ 'having a disfigurement can often lead to a lack of aspiration in education, in work, and in personal relationships, often confirmed by teachers, employers and others who have lower expectations of them';

$>$ 'this lack of aspiration and opportunity can lead to a resignation that this is how things will always be, and consequently unfairness and discrimination go unchallenged';

$>$ 'authorities who should stand up to prejudice are failing to do so effectively even when they are alerted to it.'. ${ }^{10}$

This policy brief challenges appearance-related prejudice, stereotypes and misrepresentations of disability. It also contributes to the discussion on what still needs tobe donetoenactappearance-related equality, and the acceptance of bodily diversity in more general terms. 
There is a range of examples where policy is linked with issues around appearance: following the vote by nearly one million people in 2016 in the UK Youth Parliament's ballot, who pointed to 'body image' as one of the top ten issues, the Parliamentary Youth Select Committee held dedicated sessions in July 2017 to debate related concerns. ${ }^{11}$ Internationally, several countries, including Italy, Spain and Israel, have legislated on underweight models. ${ }^{12}$ France - another country that has implemented similar laws aimed at banning the hire of extremely thin models - introduced mandatory health check requirements for workers in the fashion industry. The new French law also obliges the labelling of digitally altered images in tackling the propagation of unrealistic 'beauty' standards. ${ }^{13,14}$ These policy initiatives reflect the necessity of specific targeted measures to address looks-related prejudice and to make the principles of equality and diversity work in practice.

Many of these problems originate in the prevalent culture of obsession with appearance, which has a number of harmful consequences. Body image-related concerns in their variety of forms often cause serious mental and physical health issues. ${ }^{15,16,17}$ In the UK, disability hate crime offences increased by $101 \%$, from 1,531 in $2014-15$, to 3,079 in $2016-17 . .^{18}$

According to the Editors' Code published by the Independent Press Standards Organization (IPSO): 'The press must avoid prejudicial or pejorative reference to an individual's race, colour, religion, sex, gender identity, sexual orientation or to any physical or mental illness or disability'. 


\section{'People with a visible difference are systematically misrepresented in the media'}

Additionally, the code states: 'Details of an individual's race, colour, religion, gender identity, sexual orientation, physical or mental illness or disability must be avoided unless genuinely relevant to the story' ${ }^{19}$ Yet, people with a visible difference are systematically misrepresented in the media. 


\section{م RESEARCH EVIDENCE}

This policy brief is based on a research project by Diana Garrisi and Jacob Johanssen consisting of three strands:

1. General research into the portrayal of disfigurement in the British press

2. A study of how disfigurement as a result of acid attacks is depicted in the British media

3. A study that compares blogging about disfigurement with journalistic coverage

\section{The depiction of disfigurement and disability in the media}

In the media (especially on cinema and on television) visible differences are often depicted in a negative light, in association with evil, reclusiveness and bitterness. ${ }^{20}$ This is partly based on an association between appearance and morality which goes back at least two thousand years. ${ }^{21}$ The wider coverage of disability and bodily impairment in the UK media can be viewed as 'clichéd, stereotyped and archetypical. ${ }^{22}$ The media coverage of 'disfigurement' 
is marked by underrepresentation or misrepresentation. There are only occasional articles in the media about disfigurement and these few tend to present it within a sensational or tragic frame. ${ }^{23}$

\section{Framing disfigurement in the UK national press: tackling adjectives and adverbs}

The media do not only tend to 'tragedise' disfigurement but also underrepresent it: 'Disfigurement just doesn't exist in the media. We are invisible, and that says to me that the people running media companies don't care about us', pointed out one of the interviewees of the survey conducted by Changing Faces. ${ }^{24}$

A keyword search for the term 'disfigurement' between 2010 and 2016 in the five most read national UK broadsheets, including The Guardian; The Observer; The Times; The Independent and The Daily Telegraph, returned 867 results with the following subject breakdown:

\begin{tabular}{|l|r|}
\hline Television/Radio & $\mathbf{1 1 1}$ \\
\hline Reviews & $\mathbf{7 4}$ \\
\hline Books & $\mathbf{5 6}$ \\
\hline Domestic Politics & $\mathbf{4 3}$ \\
\hline Crime/Legal Action & $\mathbf{4 0}$ \\
\hline Movies & $\mathbf{4 0}$ \\
\hline Health & $\mathbf{3 4}$ \\
\hline Murder/Manslaughter & $\mathbf{2 7}$ \\
\hline Sports & $\mathbf{2 7}$ \\
\hline Medical Treatments/Procedures & $\mathbf{2 7}$ \\
\hline
\end{tabular}

Source: Factiva. 
The same keyword search applied to a range of the most read tabloid national newspapers, including the Daily Mail, The Sun, the Daily Star, the Daily Express and the Daily Mirror returned 770 results with the following subject breakdown:

\begin{tabular}{|l|r|}
\hline Assault & $\mathbf{1 3 3}$ \\
\hline Health & $\mathbf{6 3}$ \\
\hline Television/Radio & $\mathbf{6 2}$ \\
\hline Crime/Legal Action & $\mathbf{5 7}$ \\
\hline Medical Treatments/Procedures & $\mathbf{4 8}$ \\
\hline Celebrities & $\mathbf{3 8}$ \\
\hline Murder/Manslaughter & $\mathbf{3 5}$ \\
\hline Terrorism & $\mathbf{3 4}$ \\
\hline Arts/Entertainment & $\mathbf{3 2}$ \\
\hline Religion & $\mathbf{2 6}$ \\
\hline
\end{tabular}

Source: Factiva.

By narrowing down the sample to the first 100 articles per each of the following three broadsheets: The Guardian; The Daily Telegraph; The Times and to the three following tabloid newspapers: The Daily Mail; The Daily Mirror and The Sun, following a descending order commencing 1 January 2016, we can observe that 'disfigurement' mainly tends to feature in articles about entertainment and crime for the broadsheets; and on crime, popular medicine and entertainment in the tabloids.

These findings are tentative but a few trends can be identified: for example, overall, in the Daily Telegraph, The Times and the Guardian the majority of the stories featuring the word 'disfigurement' fell into 
categories of news related to: fiction, arts and entertainment (46\%); these often refer to cinematic characters who have a skin condition. Another $17 \%$ of the articles focused on crime, such as for example acid attacks.

\section{“disfigurement" mainly tends to feature in articles about entertainment and crime for the broadsheets; and on crime, popular medicine and entertainment in the tabloids'.}

The remaining percentage concerned life stories, sometimes told in the first person, politics, history, especially war veterans' stories, medicine and science. Overall, visible difference tends to be associated with the realm of either fantasy or crime and therefore framed as something 'not normal'.

This type of coverage reinforces the idea that disfigurement is an exceptional condition linked to exceptional circumstances while the statistics about the occurrence of disfigurement show the contrary. Although broadsheets have the tendency to avoid putting undue emphasis on cases of disfigurement, occasionally demeaning adjectives occur. In the sample of 300 broadsheets' articles analysed we found to be utilised: 'terrible' (1\%); 'horrific' (0.66\%); 'bad' (0.33\%); 'heinous' (0.3\%). Adverbs utilised to frame disfigurement include: 'horribly' (2.66\%); 'badly' (1.66\%); 'hideously' (1.66\%); 'terribly' (0.66\%); 'desperately' (0.33\%); 'horrendously' (0.33\%) and 'terrifyingly' (0.33\%).

Tabloid newspapers showed a remarkable focus on crime. For example, $47 \%$ of the 100 examined articles in the Sun newspaper concerned the topic of crime. Forty-four articles out of 100 dealt 
with bodily harm as a result of crime that resulted in disfigurement. In that context, sensationalist coverage tended to focus on detailed descriptions of the crimes themselves and the aftermath. Another key theme identified in the newspaper sample was popular medicine. For example, out of the 100 examined Mirror articles, 45 dealt only with medicine in relation to disfigurement (e.g. focussing on surgical procedures, botched surgeries that led to disfigurements, new ways of treating skin conditions). Only $5 \%$ of the Sun articles and 2\% of the Mirror articles reported on cases where disfigurement had existed as a congenital condition. This suggests that facial disfigurements are framed as conditions that are acquired as a result of a crime or a specific incident (such as an accident at work). The media fail to represent the breadth of facial disfigurements but instead focus on constructing tense 'before and after' stories that allow for the incident that led to the disfigurement to play a key role in the article. This is done in order to contrast a life-changing situation - often for the worse as the adjectives used by the journalists imply.

\section{'The media fail to represent the breadth of facial disfigurements but instead focus on constructing tense 'before and after' stories'}

A less sensationalist, negative coverage could be achieved by omitting the use of adjectives and adverbs to describe conditions. In the sample analysed it was found that the following adjectives were used to describe 'disfigurement': 'terrible' (1\%); 'catastrophic' (0.66\%); 'bad' (0.33\%); 'heart-breaking' (0.33\%); 'horrific' $(0.33 \%)$ and 'horrifying' (0.33\%). Adverbs included: 'horribly' (5.66\%); 'badly' (3\%) and 'terribly' (0.66\%). 


\section{Coverage of facial disfigurement as a result of acid attacks in the UK tabloid press}

In the UK, 66,000 people have disfigurements caused by burns and facial scars. ${ }^{25}$ Acid attacks, when corrosive substances causing burns are used, have been a growing problem in the United Kingdom and institutions are currently considering measures needed to tackle this issue. ${ }^{26}$ According to the London Metropolitan Police (MET), the number of acid attacks in London has increased significantly between 2010 and 2016 with men being twice as likely to be victims (BBC 2017). Between 2012 and 2016 acid attacks increased by more than $500 \%$ in the United Kingdom. ${ }^{27}$

The findings from the research into the coverage of facial disfigurement caused by acid attacks in the UK tabloid press ${ }^{28}$ suggest that the hero-villain dichotomy based on skin conditions, typically found in cinematic representations ${ }^{29}$, is often reversed when acid attacks are being reported. The newspaper sample consisted of the five most read tabloid newspapers in the UK, the first three of which are also the most read newspapers in general: The Daily Mail; The Sun; The Daily Mirror; The Daily Express and the Daily Star. ${ }^{30}$ The stories were retrieved from the period 2010-16 and sixteen articles were analysed qualitatively.

The individuals who received scars after having been subjected to these attacks are depicted in the light of brave resistance to violence. ${ }^{31}$ Most of these accidents are linked to domestic violence. However, generally, the attitude of the press towards disfiguring skin conditions still tends to be discriminatory. The coverage of stories about acid attack survivors has two main tendencies: one is the absence of references to wider socio-cultural aspects 
(and therefore collective responsibility) that underlie violence against women (or violence in general). Women are considered individually responsible for having been in abusive relationships and not having prevented the escalation of violence that led to these attacks. ${ }^{32}$ Another tendency is that the coverage of the aftermath of the violence and of a life with disfigurements emphasises isolation and often assumes that survivors will have to cope with physical and psychological trauma on their own, in contrast to the collective support possibilities that may be available in the community. In addition, media coverage is biased, because whilst stories of young women are given much more publicity, statistics show that men and elderly people are actually more frequent targets of acid attacks. This distorts the public perception of the problem.

\section{Journalistic representation of disfigurement versus practices of self-representation online}

Using the blog of a digital influencer who has a facial congenital condition as a case study, the other part of this research focused on the role played by the internet in rebalancing the news portrayal of diversity. The story of the British beauty blogger Katie Meehan is exemplary because it shows how the personal blog of a person with a visible difference can provide an alternative narrative to journalistic mainstream coverage. The story of Katie Meehan, who was born with a facial congenital condition called cystic hygroma, received extensive national and local media coverage for over fifteen years (over 37 articles have been published about her story). A textual analysis of the articles, shows that the press used mainly a medical and emotional framing and focused on the appearance and health-related problems caused by cystic hygroma. 


\section{'the personal blog of a person with a visible difference can provide an alternative narrative to journalistic mainstream coverage'.}

By contrast, through her blog (katiemeehan.co.uk) Katie Meehan transformed the plot from a story of disfigurement to a story of enterprise. 'With her blog, she has reaffirmed the right to media attention not as a person affected by a rare medical condition but as a digital influencer and a businesswoman who happens to have a rare congenital condition'. ${ }^{33}$ However, it must be said that the emotional rhetoric used in the press, especially the local newspaper that mainly covered her story, the Shields Gazette, also played a role in raising awareness about cystic hygroma and in raising money. Katie Meehan acknowledged the positive role of the press in a letter published in her blog. ${ }^{34,35}$ This shows that traditional forms of journalism and online forms of participatory news, such as blogging, can complement each other in shaping society's understanding of the complexities and contradictions surrounding disfigurement. ${ }^{36}$ Contradictory narratives and ways of framing disfigurement, both online and offline, highlight the fluid status of the concept of disfigurement. Disfigurement is not a static condition but rather a dynamic possibility of being, the understanding of which is heavily affected by the cultural and social context in which we live, and therefore, needs to be changed. ${ }^{37}$ 


\section{韭 REVIEW OF POLICY OPTIONS}

Currently, the policy framework in the UK is lacking, because norms enshrined in such legislation as the Equality Act or Human Rights Act are not implemented adequately. Though appearance-related discrimination is now illegal due to amendments to the 2010 Equality Act, implementation of the Act is partial and further work is required to ensure equality for all. Under the Criminal Justice Act 2003, disability hate crimes are punished by the law. However, it remains problematic to establish what falls under the heading of 'disability hate crimes' and the extent to which they differ from 'disability hate accidents.' Therefore, current legislation does not effectively tackle facial prejudice and discrimination.

The principles of inclusivity, equality and freedoms guaranteed by law should tangibly work in practice in the media. However, the Channel 4 programme 'Undateables' or the BBC 3 programme 'Freak Show' represent some of the straightforward examples of concerns that shortcomings in the enactment of equality and diversity policy in the media environment actually raise. Derogatory, negative or discouraging references must be avoided as they are stereotypes and marginalise people with unusual appearance. Singling out of visually differently-looking people 
by the core public service media channels makes it more difficult to expect that the wider public will embrace attitudes that lead to an inclusive and enabling culture towards people with different appearance or disability. As indicated previously, prejudice and stereotypes translate into very real life experiences for people subjected to them, who find themselves targets of verbal and physical assaults as well as exposed to neglect in their professional and social lives. ${ }^{38}$

Oftentimes, the authorities which are assigned the task of standing up to prejudice fail to tackle these issues effectively 'even when they are alerted to it. ${ }^{39}$ Media regulators such as the Independent Press Standards Organisation (IPSO) and the Office of Communications (Ofcom) should make a greater effort in handling complaints related to the depiction of disfigurement in the media promptly and effectively. Dame Margaret Hodge stated that the situation of people with disfigurement is holding back 'Britain's progress towards being a fair and equal society. ${ }^{30}$

\section{'the authorities which are assigned the task of standing up to prejudice fail to tackle these issues effectively "even when they are alerted to it"'.}

In its official response to the 2017 report on body image by the British Youth Council's Youth Select Committee, the UK Government recognised: 'gaps remain in our understanding of the many complex factors that contribute to body dissatisfaction, including specific challenges faced by young men, LGBT youth, ethnic minorities, and those with disabilities or serious illnesses. ${ }^{41}$ In the ministerial foreword MP Victoria Atkins added that the 
Government Equalities Office: 'has supported the development and adoption of good practice, and helped to develop young people's resilience and media literacy through the provision of resources for schools and parents. ${ }^{32}$ However, more needs to be done to implement national strategies on mediated body images aimed at promoting more inclusive body media portrayals. 


\section{$\checkmark$ POLICY RECOMMENDATIONS}

Generally, there needs to be a concerted effort to shape a community of citizens where people with visible difference are treated fairly and are given protection from discrimination. We recommend:

1. People with non-conforming physical appearance should appear more regularly on print and television as active agents in shaping media representations. For example, more space should be devoted to reporters, anchors and TV show presenters with a non-standard appearance.

2. Journalists should work in collaboration with (digital) influencers with a disfiguring condition in order to develop a more accurate and less sensational format to report on disfigurement. Those reports should focus on the everyday, lived experiences of those with a disfiguring condition and give them a voice.

3. Journalists should receive specialised training in dealing with disfigurement in a sensitive way. For example, 
the use of derogatory or pleonastic adjectives and adverbs should be strongly discouraged.

4. Magazines should use models with an unusual appearance in their covers. Influencers and beauty bloggers with a visible physical difference can play a crucial role in helping to develop an innovative life-style journalism that takes into account less normative images of bodies.

5. There needs to be a concerted effort between journalists, health care staff and legal professional bodies to ensure acid attacks are covered in an informative, non-sensational and non-spectacular way. The coverage should expand on the social nature of the problem rather than focusing exclusively on the dichotomy between victim and perpetrator.

6. Regulatory bodies like the Independent Press Standards Organisation (IPSO) and the Office of Communications (Ofcom) need to put more effort into handling complaints related to the depiction of disfigurement in the media promptly and effectively. Issuing clear and workable guidelines on the portrayal of disfigurement would also be a good step towards facilitating best practice.

7. Media skills literacy focusing on media and body image should be given greater emphasis in the school curriculum. This way, young people learn how to identify and deconstruct misrepresentations and manipulations of body images in the media. 


\section{望 NOTES}

${ }^{1}$ Changing Faces. About Disfigurement. Available at: https://www. changingfaces.org.uk/campaigns/dituk/about-disfigurement (Accessed May 2018).

${ }^{2}$ See Pearl, S. Face/On: Face Transplants and the Ethics of the Other. Chicago: University of Chicago Press (2018).

${ }^{3}$ Changing Faces. Statistics. Changing Faces. Available at: https://www.changingfaces.org.uk/resources/health/statistics (Accessed November 2017).

${ }^{4}$ Changing Faces. 2017. Disfigurement in the UK. London: Changing Faces, p. 12.

${ }^{5}$ Changing Faces, Report: Disfigurement in the UK (2017): https:// www.changingfaces.org.uk/wp-content/uploads/2017/05/ DITUK.pdf (accessed July 2017), p. 2.

${ }^{6}$ Garrisi, D. and Johanssen, J. (2018). Competing Narratives in Framing Disability in the UK Media: A Comparative Analysis of Journalistic Representations of Facial Disfigurement Versus Practices of Self-Representations Online. JOMEC Journal, 12, 128-144. https://doi.org/10.18573/jomec.172

${ }^{7}$ Changing Faces. 2017. Report: Disfigurement in the UK. Available at: https://www.changingfaces.org.uk/wp-content/ uploads/2017/05/DITUK.pdf (accessed July 2017), p. 9.

${ }^{8}$ Changing Faces, Face equality on television (no date): https:// www.changingfaces.org.uk/campaigns/face-equality/faceequality-tv (accessed July 2017). 
9 The findings were gathered through a national survey, comprising a maximum of 215 questions, delivered through the Survey Monkey platform. In total 806 people living in the UK and having a disfigurement completed the survey.

${ }^{10}$ Changing Faces, Report: Disfigurement in the UK(2017): https:// www.changingfaces.org.uk/wp-content/uploads/2017/05/ DITUK.pdf (accessed July 2017), p. 9.

${ }^{11}$ Garrisi, D. and Johanssen, J. 2017. Youth select committee inquiry: body image-related issues one of the young people's top ten concerns.'CAMRI. The Policy Observatory. 10 July. Available at: https://camri.ac.uk/blog/Articles/youth-select-committeeinquiry-body-image-related-issues-one-young-peoples-topten-concerns/.

${ }^{12}$ France passes bill banning 'excessively thin' models. BBC News, 18 December 2015. Available at: http://www.bbc.co.uk/news/ world-europe-35130792 (accessed July 2017).

${ }^{13}$ Ibid.

${ }^{14}$ France bans extremely thin models. BBC News, 6 May 2017. Available at: http://www.bbc.co.uk/news/world-europe-39821036 (accessed July 2017).

${ }^{15}$ Instagram 'worst for young mental health'. BBC News, 19 May 2017. Available at: http://www.bbc.com/news/health-39955295 (accessed July 2017).

${ }^{16}$ Media is fuelling eating disorders, say psychiatrists. BBC News, 22 February 2010. Available at: http://news.bbc.co.uk/2/ hi/8528443.stm (accessed July 2017).

${ }^{17}$ France passes bill banning 'excessively thin' models. BBC News, 18 December 2015. Available at: http://www.bbc.co.uk/news/ world-europe-35130792 (accessed July 2017).

${ }^{18}$ Kiteley, P. and Robinson, B. 2017. 'Disabled children hate crime reports increasing.' BBC News, 15 October. Available at: http://www.bbc.co.uk/news/uk-41600137 (accessed November 2017). 
19 'Editors' Code of Practice.' Independent Press Standards Organisation: https://www.ipso.co.uk/editors-code-of-practice/ (accessed May 2018).

${ }^{20}$ Wardle, C. et al. Media Coverage and Audience Reception of Disfigurement on Television. Cardiff University and Healing Foundation (2009): http://cardiff.ac.uk/jomec/resources/09m ediacoverageofdisfigurement.pdf (accessed September 2011); Croley, J. A., Reese, V., and Wagner, R. F., Dermatologic Features of Classic Movie Villains. The Face of Evil, JAMA Dermatol (2017): 153(6): 559-564. DOI: https://doi.org/10.1001/ jamadermatol.2016.5979 (accessed June 2017); read more also at Changing Faces (no date): https://www.changingfaces.org. uk/campaigns/face-equality/face-equality-film; https://www. changingfaces.org.uk/campaigns/face-equality/face-equality-film/ portrayals; https://www.changingfaces.org.uk/campaigns/ face-equality/face-equality-tv/broadcasters; https://www. changingfaces.org.uk/campaigns/face-equality/face-equality-tv (all accessed July 2017).

${ }^{21}$ Synnot, A. The Body Social: Symbolism, Self and Society. London: Routledge (1993).

${ }^{22}$ Clarke, P. A., The Changing Face of Representations of Disability in the Media' in Swain, J. et al. (eds) Disabling Barriers - Enabling Environments, second edition, London: Sage (2014), p. 100.

${ }^{23}$ Changing Faces, Report: Disfigurement in the UK(2017): https:// www.changingfaces.org.uk/wp-content/uploads/2017/05/ DITUK.pdf (accessed July 2017), p. 40.

${ }^{24}$ Cited source: Changing Faces. 2017. Disfigurement in the UK, p. 40.

${ }^{25}$ Cited source: Changing Faces. Available at: https://www. changingfaces.org.uk/resources/health/statistics.

${ }^{26}$ Home Office, Home Secretary announces action plan to tackle acid attacks, Press release (2017): https://www.gov.uk/ government/news/home-secretary-announces-action-plan- 
to-tackle-acid-attacks (accessed July 2017); UK Parliament, Acid attacks (2017): http://researchbriefings.parliament.uk/ ResearchBriefing/Summary/CBP-8041\#fullreport (accessed July 2017).

${ }^{27}$ Bryant, B. 2017. 'Everything you know about acid attacks is wrong.' $\mathrm{BBC}$ Three, November 17. Available at: http:// www.bbc.co.uk/bbcthree/item/5d38c003-c54a-4513-a369f9eae0d52f91. (Accessed: 19 November 2017).

${ }^{28}$ Johanssen, J. and Garrisi, D. (2017). 'I Am Burning, I Am Burning': Affect, Acid Attacks and British Tabloid Newspapers. Journalism Studies https://doi.org/10.1080/1461670X.2017.1389294

${ }^{29}$ Croley, J. A., Reese, V., and Wagner, R.F., Dermatologic Features of Classic Movie Villains. The Face of Evil, JAMA Dermatol (2017): 153(6): 559-564. DOI: https://doi.org/10.1001/ jamadermatol.2016.5979 (accessed June 2017)

${ }^{30}$ Ponsford, D., UK regional dailies lose print sales by average of 12.5 per cent: Wigan Post and The National are biggest fallers, Press Gazette (2017): http://www.pressgazette.co.uk/ uk-regional-dailies-lose-print-sales-by-average-of-12-5-percent-wigan-post-and-the-national-are-biggest-fallers/ (accessed July 2017).

${ }^{31}$ Johanssen, J. and Garrisi, D. (2017). 'I Am Burning, I Am Burning': Affect, Acid Attacks and British Tabloid Newspapers. Journalism Studies https://doi.org/10.1080/1461670X.2017.1389294

${ }^{32}$ This imposed perspective can be contrasted, for example, with the recent Government's action plan and a collective effort announced to stop proliferation of acid attacks as well as responsibility allocation across various segments of society, including the sales channels for corrosive substances. See Home Office, Home Secretary announces action plan to tackle acid attacks, Press release (2017): https://www.gov.uk/ government/news/home-secretary-announces-action-planto-tackle-acid-attacks (accessed July 2017); UK Parliament, Acid attacks (2017): http://researchbriefings.parliament.uk/ 
ResearchBriefing/Summary/CBP-8041\#fullreport (accessed July 2017).

${ }^{33}$ Garrisi, D. and Johanssen, J. (2018) Competing Narratives in Framing Disability in the UK Media: A Comparative Analysis of Journalistic Representations of Facial Disfigurement Versus Practices of Self-representations Online. JOMEC Journal, 12, 128-144. DOI: https://doi.org/10.18573/jomec.172.

${ }^{34}$ Meehan, K. (2017) 'A Letter To...The People Who Changed My Life.' http://katiemeehan.co.uk/2017/04/a-letter-to-the-peoplewho-changed-my-life/ (accessed May 2018).

${ }^{35}$ Kelly, T. (2012). 'Our Katie is a US internet sensation!' The Shields Gazette: https://www.shieldsgazette.com/news/our-katie-is-aus-internet-sensation-1-4633847’ (accessed May 2018).

${ }^{36}$ Ibid.

${ }^{37}$ Ibid.

${ }^{38}$ Changing Faces, Report: Disfigurement in the UK(2017): https:// www.changingfaces.org.uk/wp-content/uploads/2017/05/ DITUK.pdf (accessed July 2017).

39 Ibid, p. 9.

40 Ibid, p. 3.

${ }^{41}$ Government Equalities Office. The Government Response to the 2017 Youth Select Committee Report. (2018): http://www. byc.org.uk/wp-content/uploads/2018/03/2017-Youth-SelectCommittee-Government-Response.pdf (accessed April 2018), p. 4.

42 Ibid., p. 2. 


\section{APPEARANCE, \\ DISCRIMINATION \\ AND THE MEDIA \\ Portraying Facial Disfigurement \\ Fairly in the News}

The portrayal of disfigurement in the UK media must change. This policy brief is based on recent research that found a general negative and sensationalised attitude towards disfigurement in the media.

Disfigurement is a condition that can affect anyone at any time in life regardless their social or demographic background due to accidents or health conditions or be congenital. In the UK, one in 111 people have facial disfigurements.

In order to improve the ways in which media portray disfigurement, this policy brief argues that media should move away from sensationalised coverage on disfigurement and focus instead on the lived experiences of individuals with this condition.

It recommends strengthening diversity-oriented editorial practices and training as well as media literacy education. In addition, it addresses the lack of guidelines on the portrayal of disfigurement and urges regulatory bodies to be more efficient in handling complaints.

www.uwestminsterpress.co.uk

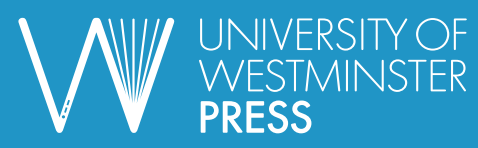

